\title{
Extracto de El Sueño de Arcadio (I)
}

DAVID BozA

$\mathrm{T}$ odo era verde. No había cielo, suelo, árboles, edificios, calles, casas ni autos; todo era verde. Mateo escuchaba a Grettel: "Es que no lo puedo creer, y ya estoy harta. Me decís que estás cansado pero me querés ver; me decís que no sabés lo que querés pero me decís que me querés... ¡No sé qué putas querés!”.

Un mar de infinito verde los rodeaba, casi tan infinito y tan verde como la distancia que había entre ellos; ellos, sentados uno a la par del otro (como pájaros en un cable de electricidad en una tarde de aguacero).

"Me decís que yo te sofoco y luego que por qué no te llamo; luego, me llamás y me echás en cara que estoy perdiendo el interés... y yo termino sintiéndome mal cuando vos sos el que tenés los problemas, yo no". Mateo con su cabeza baja escuchaba verdemente todo lo que le decían: "Ya no sé qué hacer. Hablo con mi mamá y me dice que sos un inmaduro; luego, mi hermana, que sos idiota y que nada más buscás un poco de drama. ¿iY qué puedo hacer yo!? Nada. Me seguís llamando y buscando, y yo soy la idiota inmadura que busca un poco de drama y te contesta". A Mateo, le pesaban cada vez más las orejas, quería arrancárselas $\mathrm{y}$ tirarlas por encima del horizonte verde.
"¿Qué hemos ganado en estos tres años?... ¡Nada! Solo un montón de peleas y tristezas, y desgastes y perezas... Me cortás y yo paso llorando dos semanas; luego, me buscás para volver y me decís que ese tiempo te sirvió para darte cuenta de que me extrañás y que querés volver. Pero después me volvés a cortar... Hasta recuerdo una vez que nos vimos porque me dijiste que querías que arregláramos las cosas y luego, en el momento cuando nos vimos, me dijiste que mejor no, que de camino te diste cuenta de que no querías volver... Tanto para que esa noche me llegaras a buscar llorando porque ya te habías decidido a volver... Mi pregunta no es qué tenés en la cabeza sino por qué te sigo escuchando... ¡Tres años!, llevo tres años escuchándote... y no digo nada”. La voz de Grettel era triste y resquebrajada; no lo veía, no lo podía ver, veía lo verde en su lugar. Mateo, en cambio, veía lo verde debajo de sus pies. El silencio entre ellos era muy profundo, era una caída libre como un sueño en el que se cree que uno va cayendo pero no se despierta. Mateo recordó que ayer tuvo un sueño en el que uno cree que uno va cayendo y "sabés que". Grettel lo interrumpió: "Yo ya estoy agotada de tener la misma discusión una y otra y otra vez: que yo no te entiendo, que 
no respeto tu manera de pensar y que solo pienso en mí...". El silencio volvió y se les soldó a los hombros como una cruz. Mateo sentía la vista cansada, veía todo oscuro. Cerró los ojos por unos segundos; cuando los abrió, todo era verde nuevamente.

"Y luego yo te digo que te siento distante y que no nos comunicamos y que no me dejás expresar lo que siento... No sé qué hacer, ya no sé qué hacer".
Verde. "Y siento que hemos dicho tantas cosas que ya nuestras palabras no tienen sentido; es que nada tiene sentido. Tres años; es ilógico que estemos teniendo la misma conversación una y otra vez". Mateo sintió que quería tocarla, abrazarla, pero en cambio la miró y le dijo: "Todo era verde. No había cielo, suelo, árboles, edificios, calles, casas ni ni autos; todo era verde...".

\section{Extracto de El Sueño de Arcadio (II)}

DAVID Boza

L

a noche estaba fría en las calles de la capital. Las pocas personas que deambulaban a las 9:00 p. m. eran las últimas gotas de un aguacero de gentes, las cuales caminaban horas antes como endiabladas para llegar lo más pronto posible a sus casas y olvidarse de sus trabajos. Aún más, estos pocos individuos, pordioseros de las horas pico, caminaban tranquilamente por la soledad de un martes en la noche, ya fuera porque su trabajo requería del cumplimiento de horas extras o por la aparición de una reunión de último momento, o por la búsqueda de cualquier pretexto para ir en contra de la marea de muertos vivientes volviendo a sus tumbas para preparase para escribir, al día siguiente, otra página de sus vidas con una fotocopiadora en lugar de una máquina de escribir.

En el caso de Mateo, él utilizaba en un día como este la excusa de sus seminarios acerca de grandes pensadores de la historia para huir de la monotonía del mundo moderno basado en lo que él llamaba una economía de prostitución de la fuerza laboral. Estos seminarios eran parte de la vida de un individuo racional a la cual dedicaba la mayor parte de su tiempo libre; cuando no estaba dando clases de Sociología en la Universidad Estatal, dedicaba su tiempo a aprender latín, asistir a su grupo de debate los lunes, practicar guitarra 
clásica, asistir a sus seminarios de los martes o tertuliar en el Café de los Sueños con su colectivo de amigos intelectuales y artistas. Invertía todo su tiempo libre en cultivar su mente, ya que él, como racionalista, utilitarista, empirista, analista, estructuralista, intelectualista, materialista, neoclasista, feminista, formalista, humanista, objetivista, marxista y positivista, creía ciegamente que el intelecto humano era la clave para conocer y entender el fenómeno tan intrigante y complejo que representa la existencia humana. En su danza con la soledad, cada paso lo daba con orgullo, cada paso era un logro de sus evolucionadas capacidades mentales. Estaba consciente de que su subconsciente se encargaba de mover sus piernas de tal manera que pudiera trasladar toda su masa corporal de un punto a otro en el espacio. Además, el hecho de que sus pasos resonaran en la soledad de las calles, al contrario de la estúpida masa que se encontraba en su casa ofreciendo en sacrificio sus neuronas a la diosa de plasma, creaba un sentimiento de satisfacción en su corazón.

Después de dar la vuelta en una esquina, los pasos de Mateo se detuvieron ante lo que a sus ojos parecía un tigre de por lo menos $250 \mathrm{~kg}$ de peso que rebuscaba entre unas bolsas de basura tiradas en un caño. Su estupefacta cara demostraba su sentimiento de confusión. Pensó que era tanto teórica como prácticamente imposible avistar lo que parecía un tigre chino en las abandonadas calles de la gris capital de un país tropical como Costa Pobre, con condiciones climatológicas y geográficas tan inhóspitas para la subsistencia de un Panthera Tigris. Mateo lo observó por un momento; era una bestia magnífica, como esculpida por las palabras de Blake; su pelaje era anaranjado intenso, a tal punto que parecía irradiar luz propia. Tenía rayas negras y espesas como el alquitrán. Sus patas eran musculosas y se desbordaban en unas descomunales garras capaces de partir en dos a un ser humano con solo una caricia. Mateo no había escuchado ese día reporte alguno acerca de un felino de tales dimensiones que se encontrara prófugo del Zoológico Metropolitano. Inclusive, hasta donde él tenía entendido, no existía ningún ejemplar de esta especie en el Metropolitano, el único zoológico de la capital. Ante tantas interrogantes sin respuesta, sus labios pronunciaron en medio de la soledad de la noche: "imposible." Al escucharlo, el tigre desvió su atención de las bolsas de basura y lo observó con una mirada fija y penetrante, casi irreal. Un segundo después, se le abalanzó encima.

A la mañana siguiente, los muertos vivientes que se detenían camino a sus trabajos para comprar el periódico Todo Tuanis pudieron leer en la primera plana en encabezado ENCUENTRAN LOS HUESOS DE PROFESOR UNIVERSITARIO EN BOLSAS DE BASURA EN MEDIA ACERA DE LA CAPITAL. 


\section{Extracto de El Sueño de Arcadio (III)}

DaVID BozA

$\mathrm{E}$ 1 otro día se me acercó Mateo y me dijo que se le había ocurrido una idea maravillosa. Me dijo "Julio, se me ha ocurrido una idea maravillosa. Imaginate que uno fuera capaz de desenroscarse las partes del cuerpo. ¡Qué genialidad! Imaginate las posibilidades. Serías capaz de desenroscarte las piernas cuando te estorben o de utilizar tu brazo desenroscado como si fuera un gancho para tocar el timbre del autobús sin tener que ponerte de pie". Me parecían un poco extrañas sus palabras. "Podrías desenroscarte un dedo y dejárselo en el escritorio a la muchacha que te gusta en el trabajo para así tener un tema de conversación:
'Disculpá, ¿por casualidad no has visto un pulgar por aquí?'. O podrías lanzarle una oreja a un compañero de trabajo que esté hablando mucha mierda para que se calle. Hasta podrías desenroscarte un pie y tirárselo al puto Pablo de arlequín cuando te llega a despertar en medio de la noche". Me pareció una idea bastante estúpida. Pero a mí sí me sobrevino una idea extraordinaria: ¿Qué pasaría si uno fuera capaz de desenroscarse las partes del cuerpo y pudiera lanzarlas, utilizarlas y dejarlas olvidadas a conveniencia? Uno hasta podría lanzarle un pie a la mujer en el sillón rojo cuando llegue a molestar en medio de la oscuridad de la noche. 